\title{
Complement factor I deficiency
}

\section{A potentially treatable cause of fulminant cerebral inflammation}

\author{
Tom Altmann, MRes, MBBS, Megan Torvell, PhD, Stephen Owens, MB ChB PhD, \\ Dipayan Mitra, MBBS, MD, MRCP, FRCR, Neil S. Sheerin, BSc, PhD, FRCP, \\ B. Paul Morgan, MB BCh, PhD, FRCPath, David Kavanagh, BSc, MBChB, PhD, FRCP, and \\ Rob Forsyth, BM BCh, PhD, FRCPCH
}

Neurol Neuroimmunol Neuroinflamm 2020;7:e689. doi:10.1212/NXI.0000000000000689

\author{
Correspondence \\ Dr. Forsyth \\ rob.forsyth@newcastle.ac.uk
}

\begin{abstract}
Objective

To raise awareness of complement factor I (CFI) deficiency as a potentially treatable cause of severe cerebral inflammation.
\end{abstract}

\section{Methods}

Case report with neuroradiology, neuropathology, and functional data describing the mutation with review of literature.

\section{Results}

We present a case of acute, fulminant, destructive cerebral edema in a previously well 11-yearold, demonstrating massive activation of complement pathways on neuropathology and compound heterozygote status for 2 pathogenic mutations in CFI which result in normal levels but completely abrogate function.

\section{Conclusions}

Our case adds to a very small number of extant reports of this phenomenon associated with a spectrum of inflammatory histopathologies including hemorrhagic leukoencephalopathy and clinical presentations resembling severe acute disseminated encephalomyelitis. CFI deficiency can result in uncontrolled activation of the complement pathways in the brain resulting in devastating cerebral inflammation. The deficit is latent, but the catastrophic dysregulation of the complement system may be the result of a C3 acute phase response. Diagnoses to date have been retrospective. Diagnosis requires a high index of suspicion and clinician awareness of the limitations of first-line clinical tests of complement activity and activation. Simple measurement of circulating CFI levels, as here, may fail to diagnose functional deficiency with absent CFI activity. These diagnostic challenges may mean that the CFI deficiency is being systematically under-recognized as a cause of fulminant cerebral inflammation. Complement inhibitory therapies (such as eculizumab) offer new potential treatment, underlining the importance of prompt recognition, and real-time whole exome sequencing may play an important future role. 


\section{Glossary}

ADEM = acute disseminated encephalomyelitis; AHLE = acute hemorrhagic leukoencephalopathy; aHUS = atypical haemolytic uraemic syndrome; $\mathbf{A P}=$ alternative pathway; $\mathbf{C F B}=$ complement factor $\mathrm{B} ; \mathbf{C F H}=$ complement factor $\mathrm{H}$; $\mathbf{C F I}=$ complement factor I; FFp = fresh frozen plasma; WES = whole exome sequencing.

We report a case of life-threatening, nonhemorrhagic fulminant CNS inflammation, radiologically resembling acute disseminated encephalomyelitis (ADEM), in association with complete complement factor I (CFI) functional deficiency. A very few such cases have been reported to date, all identified retrospectively via whole exome sequencing (WES) and/or known family history. Complement inhibition (e.g., with eculizumab) represents a potential therapeutic option in this otherwise devastating illness but would require prompt recognition. The index case had a functional CFI deficiency (with normal serum CFI levels), emphasizing that simple serum complement assays will not exclude CFI deficiency and the challenge of timely diagnosis. CFI deficiency may be an under-recognized cause of encephalitis of "presumed viral" or unknown etiology. Improved outcome will require greater awareness of the condition and a high index of suspicion.

\section{Case}

An 11-year-old Caucasian girl presented with a 5 days history of fever, headache, and vomiting. She had no significant medical history and no recent foreign travel. Initial GCS was 14 of 15 but rapidly fell to 8 . She was intubated and ventilated. Temperature on admission was $37.6^{\circ} \mathrm{C}$. White blood cell count was $14.3 \mathrm{~mm}^{-3}$, with $90 \%$ neutrophils with an erythrocyte sedimentation rate of $103 \mathrm{~mm}^{-} / \mathrm{h}$. C-reactive protein was $201 \mathrm{mg} / \mathrm{L}$.

Initial CT of the head showed no bleed or mass. Initial MRI (figure 1) demonstrated bilateral, asymmetrical, predominantly white matter edema with posterior corpus callosal changes; some gray matter involvement of thalami; and patchy enhancement postcontrast. There was no restricted diffusion. She developed rapidly progressive, life-threatening cerebral edema requiring an external ventricular drain followed by bifrontal decompressive craniectomy at which point a superficial cortical brain biopsy was obtained. There were no significant light microscopic abnormalities. Immunohistochemical studies showed no evidence of a demyelinating process with few $\mathrm{T}$ cells in the tissue. There was marked astrogliosis (indicated by glial fibrillary acidic protein staining, figure $2 \mathrm{E}$ ) and microgliosis (ionized calcium binding adapter molecule 1 staining, figure $2 \mathrm{~F}$ ) accompanied by deposition of $\mathrm{C} 3 \mathrm{~b} / \mathrm{iC} 3 \mathrm{~b}$ (figure $2 \mathrm{G}$ ) and terminal complement complex (figure $2 \mathrm{~F}$ ), both of which appear neuronal in location.

She was treated with ceftriaxone and aciclovir for presumed meningoencephalitis, high-dose methylprednisolone ( $1 \mathrm{~g}$ daily for 5 days), followed by an extended high-dose enteral prednisolone taper; plasmapheresis with human albumin solution and fresh frozen plasma (FFP) (days 5-15 inclusive); and rituximab (total $1125 \mathrm{mg} / \mathrm{m}^{2}$ in 2 doses, days 6 and 21 , because of concern about possible washout of the first dose with plasmapheresis) for a working diagnosis of severe ADEM. There was little obvious benefit. The severely elevated intracranial pressure began to settle around day 6. By day 14 , some withdrawal from painful stimuli was noted. Blood and CSF cultures were negative for primary bacterial infection. CSF virology was negative for herpes simplex, varicella, Enterovirus, and Parechovirus by PCR. An initial CSF sample was heavily blood-stained with protein $0.81 \mathrm{~g} / \mathrm{L}$ and 30,000 erythrocytes/ $\mathrm{mm}^{3}$ but no excess of CSF leukocytes. Subsequent CSF samples showed no CSF leukocytes. Antibodies to myelinoligodendrocyte glycoprotein, aquaporin 4, glycine receptors, voltage-gated potassium channel-related proteins, and NMDA receptors were all negative. Immunoglobulin levels at presentation were normal.

Retrospectively, a neuroinflammatory gene panel identified 2 pathogenic CFI variants (c.1019T $>C$ p. $($ Ile340Thr) and c.1555 G>A p.(Asp519Asn). Subsequent Sanger sequencing of the proband and parents confirmed compound heterozygote status. Subsequent complement assays were performed 8 months after presentation. $\mathrm{C} 3$ and $\mathrm{C} 4$ were within the normal range (0.72 [normal range (NR) $0.68-1.80]$ and 0.35 [NR $0.18-0.6] \mathrm{g} / \mathrm{L}$, respectively). CFI and complement factor $\mathrm{H}$ $(\mathrm{CFH})$ were within the normal range $(29 \mathrm{mg} / \mathrm{L}$ [NR 21-40] and 0.59 [NR $0.56-0.94] \mathrm{g} / \mathrm{L}$, respectively). There was marked activation of the alternative pathway (AP) with markedly low complement factor B (CFB; $49 \mathrm{mg} / \mathrm{L}: \mathrm{NR}>186 \mathrm{mg} / \mathrm{L})$ and absent AP haemolytic activity (AP100).

Nearly 2 years from presentation, the patient has been left with a profound neurologic deficit with tetraplegia, although she can write slowly with specialist aids indicating relative cognitive preservation. A seizure disorder is well controlled with levetiracetam. She has commenced penicillin prophylaxis and has been immunized against capsulated organisms in light of the absent AP activity. Follow-up imaging at 6 months showed severe widespread atrophy with no new signal abnormality (supplemental data figure 2, links.lww.com/NXI/ A208).

\section{Discussion}

We describe a patient with compound heterozygote, complete CFI deficiency, with a nonclassic, neurologic presentation. CFI is a complement regulatory protein that inactivates all pathways 


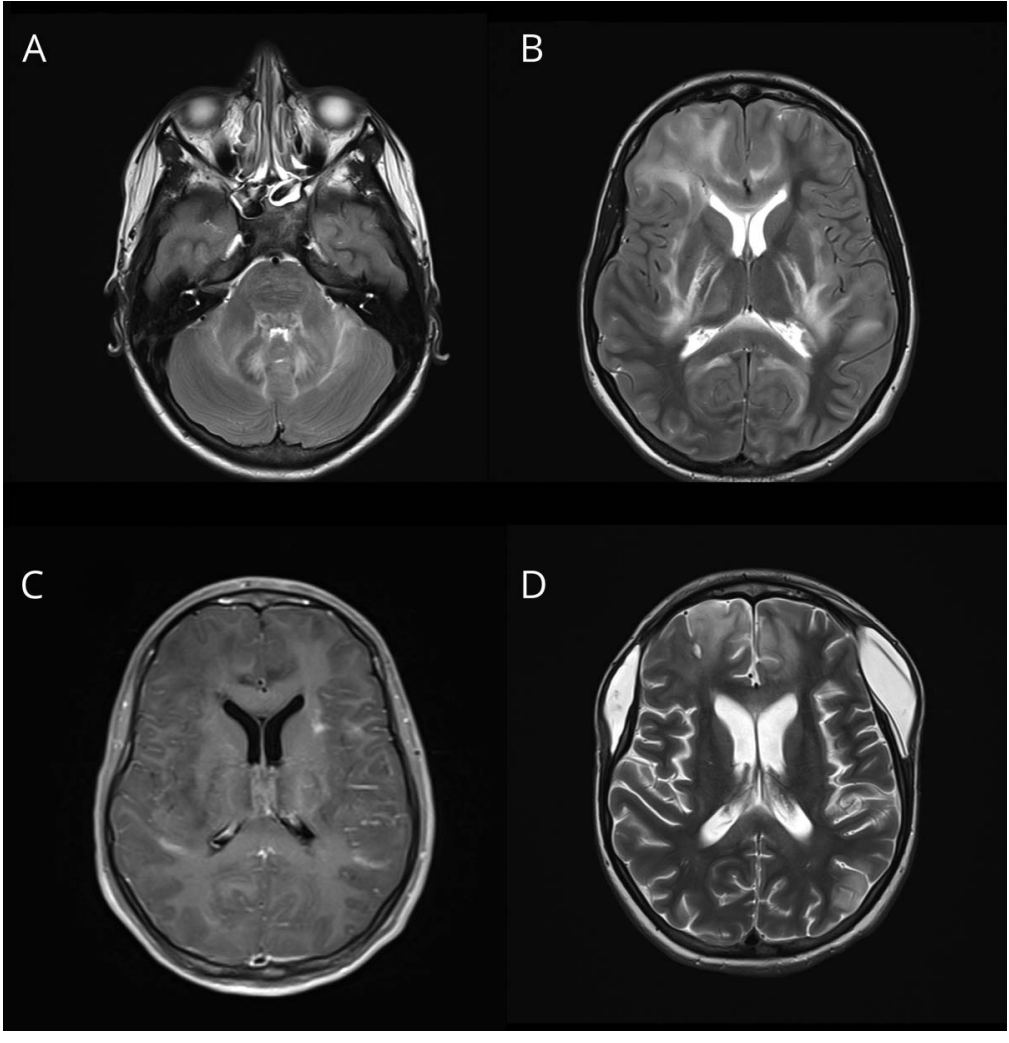

Representative neuroradiologic images. (A-C) Acute imaging on day 2 of admission shows bilateral, asymmetrical, predominantly white matter changes, although some gray matter involvement of thalami is also seen. Patchy enhancement postcontrast and mass effect and effacement of the sulci. Diffusion-weighted imaging (not shown) did not indicate any area of restricted diffusion. (D) Approximately 1 month later showing postcraniectomy changes and substantial resolution of the acute inflammation. $(A, B$, and $D=$ T2-weighted; C = postcontrast T1-weighted). of the complement system by cleaving the $\alpha^{\prime}$-chains of C3b and $\mathrm{C} 4 \mathrm{~b}$ (figure 3). Complete CFI deficiency is believed to be rare and, as would be predicted, has mainly been reported in association with primary infection (including CNS infection) with encapsulated microorganisms. ${ }^{1}$ Heterozygote status for
CFI deficiency has been associated with atypical hemolytic uraemic syndrome (aHUS) (i.e., not associated with Escherichia coli gastroenteritis) ${ }^{2}$ and age-related macular degeneration. ${ }^{3}$ CFI-mediated complement regulation may also be important in the progression of early phase Alzheimer disease. ${ }^{4}$

Figure 2 Immunohistochemistry
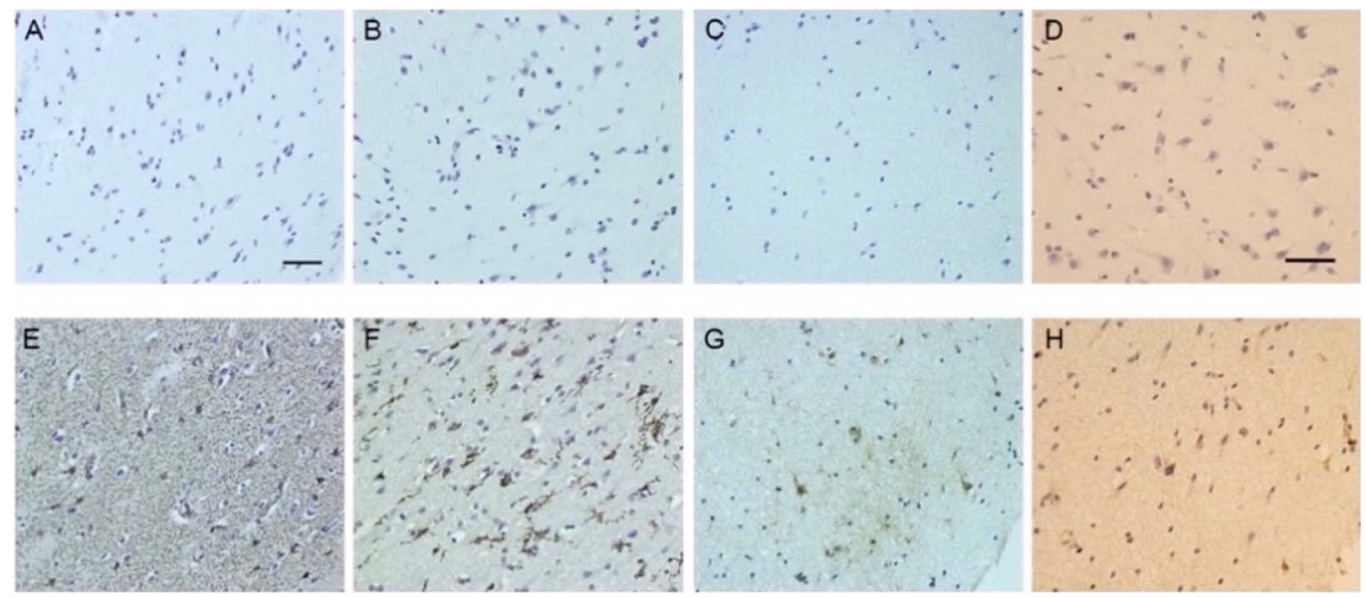

Immunohistochemistry of parietal cortical sample obtained at the time of craniectomy demonstrate reactive astrogliosis, microgliosis, and complement deposition. Top row (A-D) indicates controls (secondary antibody only). Bottom row (E-H) indicates antibody staining. A and E, Reactive astrocyte marker glial fibrillary acidic protein. B and F, Pan-microglial marker ionized calcium binding adapter molecule 1. C and G, In-house anti-C3b/iC3b monoclonal antibody C3/30. D and H, Anti-C9 neoantigen-specific monoclonal antibody B7 (membrane attack complex). Scale bars $=50 \mu \mathrm{m}$. 


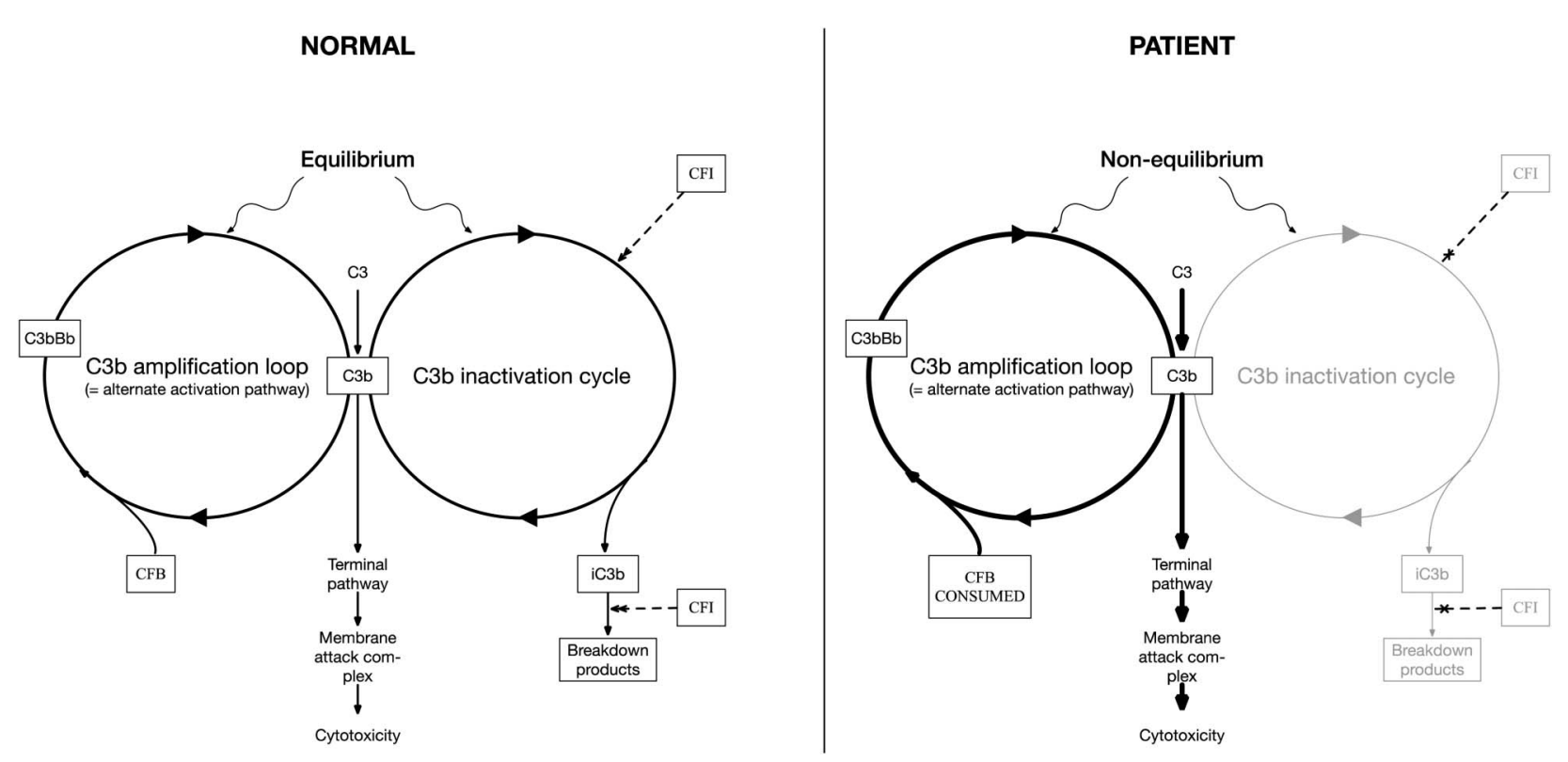

Highly simplified cartoon of complement amplification loop pathways indicating (left, normal healthy condition) how C3/C3b levels reflect an equilibrium between 2 cycles: one of C3 cleavage to form C3b that interacts with factor B, which is then cleaved by factor D to form the C3 convertase (C3bBb) to cleave more C3 and a CFI-dependent C3b inactivation cycle. In factor I deficiency (right), a lack of C3b inactivation causes uncontrolled accumulation of C3b, rapid consumption of $\mathrm{C} 3$, and activation of the downstream terminal pathway. Excessive activation of the C3b amplification loop can be inferred from CFB levels that are markedly reduced because of consumption. CFB = complement factor B; CFI = complement factor I.

A report of 2 unrelated children of Filipino descent ${ }^{5}$ and a recent adult brief report ${ }^{6}$ describe acute hemorrhagic leukoencephalopathy (AHLE) in association with complete CFI deficiency. All had infrequently recurrent episodes, at intervals of several years, commencing in the second decade of life. Radiologically, our case resembles case B in Shields et al., ${ }^{6}$ but appears uniquely severely affected among cases reported to date.

We speculate that the basis for such infrequent, fulminant presentations may be that the CFI deficiency causes chronic AP activation limited only by depletion of its substrate C3. C3 is an acute phase protein. and stressors such as viral infection may result in a rapid surge in C3 production, freeing the previously substrate-limited $\mathrm{AP}$ and resulting in a catastrophic runaway that overwhelms downstream complement regulators (which are in any case poorly expressed in the brain). In this context, one could hypothesize that our use of plasmapheresis with FFP may have been deleterious because of delivery of exogenous (functional) factor I and C3, facilitating proinflammatory conversion of $\mathrm{C} 3 \mathrm{~b}$ to $\mathrm{iC} 3 \mathrm{~b}$ (figure 3 ), although no clinical deterioration was detectable at the time. We were not able to identify an infective trigger in our case although she had been pyrexial before admission.

Our case had no radiologic or pathologic evidence of hemorrhage, suggesting an AHLE phenotype is not consistent and that neuroradiologic appearances can resemble acute demyelination. Complement activation is a recognized pathophysiologic mechanism in neuromyelitis optica and related disorders, ${ }^{7,8}$ suggesting a basis for similar radiologic appearances.
Improved outcomes are likely to depend on prompt recognition of the CFI deficiency to administer anticomplement drugs. This case highlights several diagnostic pitfalls. The patient's I340T and D519N variants have been reported (as heterozygotes) in association with aHUS (see supplemental data, links.lww.com/ NXI/A208). In both instances, absolute levels of CFI were normal; however, functional analysis demonstrated almost complete abrogation of enzymatic activity. ${ }^{9}$ Thus, unlike previous cases, ${ }^{5}$ our patient was in the highly unusual situation of having antigenically normal CFI levels but severely deficient CFI activity from both mutant alleles. In addition, the unexpected finding of normal serum C3 level in the serum reflects the fact that routine clinical assays may also detect other forms of $\mathrm{C} 3$, in this setting, most likely $\mathrm{C} 3 \mathrm{~b}$. The most reliable routinely clinically available diagnostic clue in this situation is the markedly reduced CFB level that reflects excessive CFB consumption because of a lack of inhibition of the amplification loop (figure 3).

In keeping with other reports, ${ }^{5}$ our patient showed no response to plasma exchange or rituximab, although case B in Shields et al. ${ }^{6}$ did show a response to methylprednisolone. Broderick et al. ${ }^{5}$ saw modest benefits coinciding with anakinra use. Eculizumab is the only currently available complement inhibitor. It is a monoclonal antibody that specifically binds to C5 and blocks its cleavage, preventing formation of the membrane attack complex and C5a release. There is growing interest in the potential of eculizumab in severe autoimmune demyelinating neuroinflammatory disease, particularly anti-aquaporin 4-mediated neuromyelitis optica. ${ }^{8}$ In future cases of unexplained ADEM or AHLE, we suggest that clinicians investigate the presence of a potential complement 
regulation defect via extended complement assays (including complement function, activation products, and levels of CFI, $\mathrm{CFH}$, and $\mathrm{CFB})$. Real-time $\mathrm{WES}^{10}$ may also play an important future role in diagnosis. The identification of complement regulator defects would provide a biological rational for the use of eculizumab and the next wave of 2 nd generation complement inhibitory therapies.

Deidentified clinical data will be made available on appropriate request to the corresponding author.

\section{Study funding}

B.P. Morgan has RCUK funding, and D. Kavanagh has NIHR UK funding.

\section{Disclosure}

T. Altmann, M. Torvell, S. Owens, and D. Mitra report no disclosures relevant to the manuscript. N.S. Sheerin has received honoraria for talks and advisory boards for Alexion Pharmaceuticals and Novartis. B.P. Morgan reports no disclosures relevant to the manuscript. D. Kavanagh is a director of and scientific advisor to Gyroscope Therapeutics. He has received honoraria for consultancy work from Alexion, Idorsia, Apellis, and Novartis. R. Forsyth reports no disclosures relevant to the manuscript. Go to Neurology.org/NN for full disclosures.

\section{Publication history}

Received by Neurology: Neuroimmunology \& Neuroinflammation November 19, 2019. Accepted in final form January 21, 2020.

\section{Appendix Authors}

\begin{tabular}{|c|c|c|c|}
\hline Name & Location & Role & Contribution \\
\hline $\begin{array}{l}\text { Tom } \\
\text { Altmann, } \\
\text { MRes, MBBS }\end{array}$ & $\begin{array}{l}\text { Newcastle upon Tyne } \\
\text { Hospitals NHS } \\
\text { Foundation Trust, } \\
\text { United Kingdom }\end{array}$ & Author & $\begin{array}{l}\text { Major role in the } \\
\text { acquisition of data; } \\
\text { drafted the } \\
\text { manuscript for } \\
\text { intellectual content }\end{array}$ \\
\hline $\begin{array}{l}\text { Megan } \\
\text { Torvell, PhD }\end{array}$ & $\begin{array}{l}\text { Cardiff University, } \\
\text { United Kingdom }\end{array}$ & Author & $\begin{array}{l}\text { Major role in the } \\
\text { acquisition of data }\end{array}$ \\
\hline $\begin{array}{l}\text { Stephen } \\
\text { Owens, MB } \\
\text { ChB, PhD }\end{array}$ & $\begin{array}{l}\text { Newcastle upon Tyne } \\
\text { Hospitals NHS } \\
\text { Foundation Trust, } \\
\text { United Kingdom }\end{array}$ & Author & $\begin{array}{l}\text { Interpreted the data; } \\
\text { revised the } \\
\text { manuscript for } \\
\text { intellectual content }\end{array}$ \\
\hline
\end{tabular}

Appendix (continued)

\begin{tabular}{|c|c|c|c|}
\hline Name & Location & Role & Contribution \\
\hline $\begin{array}{l}\text { Dipayan } \\
\text { Mitra, } \\
\text { MBBS, MD, } \\
\text { MRCP, FRCR }\end{array}$ & $\begin{array}{l}\text { Newcastle upon Tyne } \\
\text { Hospitals NHS } \\
\text { Foundation Trust, } \\
\text { United Kingdom }\end{array}$ & Author & $\begin{array}{l}\text { Interpreted the data; } \\
\text { revised the } \\
\text { manuscript for } \\
\text { intellectual content }\end{array}$ \\
\hline $\begin{array}{l}\text { Neil S. } \\
\text { Sheerin, } \\
\text { BSc, PhD, } \\
\text { FRCP }\end{array}$ & $\begin{array}{l}\text { Newcastle University, } \\
\text { United Kingdom }\end{array}$ & Author & $\begin{array}{l}\text { Interpreted the data; } \\
\text { revised the } \\
\text { manuscript for } \\
\text { intellectual content }\end{array}$ \\
\hline $\begin{array}{l}\text { B. Paul } \\
\text { Morgan, MB } \\
\text { BCh, PhD, } \\
\text { FRCPath }\end{array}$ & $\begin{array}{l}\text { Cardiff University, } \\
\text { United Kingdom }\end{array}$ & Author & $\begin{array}{l}\text { Interpreted the data; } \\
\text { revised the } \\
\text { manuscript for } \\
\text { intellectual content }\end{array}$ \\
\hline $\begin{array}{l}\text { David } \\
\text { Kavanagh, } \\
\text { BSC, } \\
\text { MBChB, } \\
\text { PhD, FRCP }\end{array}$ & $\begin{array}{l}\text { Newcastle University, } \\
\text { United Kingdom }\end{array}$ & Author & $\begin{array}{l}\text { Major role in the } \\
\text { acquisition of data; } \\
\text { revised the } \\
\text { manuscript for } \\
\text { intellectual content }\end{array}$ \\
\hline $\begin{array}{l}\text { Rob } \\
\text { Forsyth, BM } \\
\text { BCh, PhD, } \\
\text { FRCPCH }\end{array}$ & $\begin{array}{l}\text { Newcastle University, } \\
\text { United Kingdom }\end{array}$ & Author & $\begin{array}{l}\text { Major role in the } \\
\text { acquisition of data; } \\
\text { drafted and revised } \\
\text { the manuscript for } \\
\text { intellectual content }\end{array}$ \\
\hline
\end{tabular}

\section{References}

1. Nilsson SC, Sim RB, Lea SM, Fremeaux-Bacchi V, Blom AM. Complement factor I in health and disease. Mol Immunol 2011;48:1611-1620.

2. Kavanagh D, Kemp EJ, Mayland E, et al. Mutations in complement factor I predispose to development of atypical hemolytic uremic syndrome. J Am Soc Nephrol 2005;16: 2150-2155.

3. Seddon JM, Yu Y, Miller EC, et al. Rare variants in CFI, C3 and C9 are associated with high risk of advanced age-related macular degeneration. Nat Genet 2013;45: 1366-1370.

4. Hakobyan S, Harding K, Aiyaz M, et al. Complement biomarkers as predictors of disease progression in alzheimer's disease. J Alzheimers Dis 2016;54:707-716.

5. Broderick L, Gandhi C, Mueller JL, et al. Mutations of complement factor I and potential mechanisms of neuroinflammation in acute hemorrhagic leukoencephalitis. J Clin Immunol 2012;33:162-171.

6. Shields AM, Pagnamenta AT, Pollard AJ, et al. Classical and non-classical presentations of complement factor I deficiency: two contrasting cases diagnosed via genetic and genomic methods. Front Immunol 2019;10:1150.

7. Mader S, Gredler V, Schanda K, et al. Complement activating antibodies to myelin oligodendrocyte glycoprotein in neuromyelitis optica and related disorders. J Neuroinflammation 2011;8:184.

8. Pittock SJ, Berthele A, Fujihara K, et al. Eculizumab in aquaporin-4-positive neuromyelitis optica spectrum disorder. N Engl J Med 2019;381:614-625.

9. Kavanagh D, Richards A, Noris M, et al. Characterization of mutations in complement factor I (CFI) associated with hemolytic uremic syndrome. Mol Immunol 2008;45: 95-105.

10. Saunders CJ, Miller NA, Soden SE, et al. Rapid whole-genome sequencing for genetic disease diagnosis in neonatal intensive care units. Sci Transl Med 2012;4: $154 \mathrm{ra} 135$. 


\section{Neurology \\ Neuroimmunology \& Neuroinflammation}

\section{Complement factor I deficiency: A potentially treatable cause of fulminant cerebral inflammation}

Tom Altmann, Megan Torvell, Stephen Owens, et al.

Neurol Neuroimmunol Neuroinflamm 2020;7;

DOI 10.1212/NXI.0000000000000689

This information is current as of February 25, 2020

Updated Information \&

Services

References

Citations

Subspecialty Collections

Permissions \& Licensing

Reprints including high resolution figures, can be found at:

http://nn.neurology.org/content/7/3/e689.full.html

This article cites 10 articles, 2 of which you can access for free at: http://nn.neurology.org/content/7/3/e689.full.html\#\#ref-list-1

This article has been cited by 1 HighWire-hosted articles: http://nn.neurology.org/content/7/3/e689.full.html\#\#otherarticles

This article, along with others on similar topics, appears in the following collection(s):

All Demyelinating disease (CNS)

http://nn.neurology.org//cgi/collection/all_demyelinating_disease_cns All Immunology

http://nn.neurology.org//cgi/collection/all_immunology

Critical care

http://nn.neurology.org//cgi/collection/critical_care

Information about reproducing this article in parts (figures,tables) or in its entirety can be found online at:

http://nn.neurology.org/misc/about.xhtml\#permissions

Information about ordering reprints can be found online:

http://nn.neurology.org/misc/addir.xhtml\#reprintsus

Neurol Neuroimmunol Neuroinflamm is an official journal of the American Academy of Neurology.

Published since April 2014, it is an open-access, online-only, continuous publication journal. Copyright

Copyright $\odot 2020$ The Author(s). Published by Wolters Kluwer Health, Inc. on behalf of the American

Academy of Neurology.. All rights reserved. Online ISSN: 2332-7812.

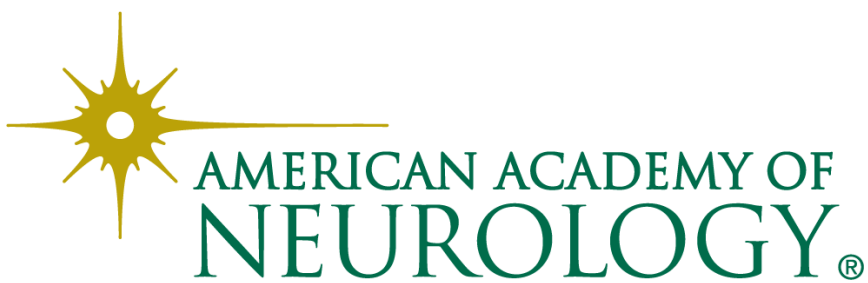

